\title{
EXPERIMENTAL INVESTIGATION OF HARROW WITH SPRING TEETH FOR CULTIVATION OF SUGAR BEETS
}

\author{
Volodymyr Bulgakov ${ }^{1}$, Semjons Ivanovs ${ }^{2}$, Valentyna Bandura ${ }^{3}$, Yevhen Ihnatiev ${ }^{4}$ \\ ${ }^{1}$ National University of Life and Environmental Sciences of Ukraine, Ukraine; \\ ${ }^{2}$ Latvia University of Life Sciences and Technologies, Latvia; \\ ${ }^{3}$ Vinnytsia National Agrarian University of Ukraine, Ukraine; \\ ${ }^{4}$ Tavria State Agrotechnological University, Ukraine \\ semjons@apollo.lv
}

\begin{abstract}
In accordance with contemporary technologies, the fight against contamination of sugar beet crops by multiple applications of herbicides, which are environmentally hazardous, is carried out. In the biological cultivation of beets, the use of chemical preparations is not allowed. The purpose of this study was experimental determination of a possibility for efficient thinning sugar beet plantations with the help of a new spring-toothed harrow, which has mechanical selectivity with respect to the shoots of weeds. The revealed agrotechnical differences between the shoots of the sugar beet and the common weeds made it possible to substantiate the design peculiarities of the new harrow with spring teeth. The new harrow with the chain-spring operating tools in an optimal operating mode in the range of the soil moisture $(W=14-20 \%)$ ensures destruction of the weed shoots - from 60 to $75.1 \%$ with a removal of the sugar beet shoots from 3 to $5 \%$ (mostly poorly developed or diseased plants). The conducted field tests of the harrow with the chain-spring teeth showed its efficiency and advantages over the other existing harrow designs in the care for sugar beet plantations without application of herbicides. The research results of a harrow with chain-type working tools showed that, in contrast to the existing serial specimens, it removes up to 5 times less sugar beet shoots, and destroys by 11-15\% more weeds. This harrow can find application on the fields for ecologically clean management of soil cultivation on the farms and other private households.
\end{abstract}

Keywords: sugar beet, harrow, spring tooth, shoots, weeds.

\section{Introduction}

In accordance with the modern technologies used in agriculture, multiple applications of herbicides are practiced to combat the weediness of sowings, introduction of which into the soil is considered environmentally undesirable or dangerous. In the case of biological (ecological) land farming, the use of chemical preparations is not allowed and the problem of the weed control becomes especially urgent. In the recent years biological agriculture (organic farming) in the developed countries has a steady tendency to increase the areas of plantations [1]. Seeking more sophisticated mechanical methods for the weed control remains also topical at the present time when cultivating other agricultural crops [2-4]. The use of manual labour in such operations is now also practically eliminated due to high costs, etc.

Harrowing of the sowings is an old and sufficiently simple common agrotechnical way of the weed control [3], including in the beet cultivation. Nevertheless, this method, based on the existing tools (tooth harrows, rotary hoes, etc.) is not efficient enough due to the fact that an insufficient number of the weed shoots is destroyed using it and, at the same time, a large proportion of the shoots of the cultivated plants is damaged.

A lot of researchers have worked to solve the problem how to create a reliable and efficient working tools and tools for the weed control on the cultivated crop plantations [5-7]. However, despite the large number of the existing designs, unfortunately, they do not possess sufficient mechanical selectivity and high level of weed destruction. Thus, research in this area is pressing, especially with respect to the development of the ecological land farming. At the same time, the main issue is the question, which working tool is able to implement the idea of mechanical selectivity for removal of the shoots of different plants?

The purpose of this study is to determine the force, with which the sugar beet shoots and the most common weeds are extracted from the soil, and to evaluate experimentally a possibility of efficient weed removal using the new spring-tooth harrow that has mechanical selectivity towards the beet shoots. 


\section{Materials and methods}

Methods of field testing of agricultural machines and processing the results on a PC were used during the experimental research with a possibility to evaluate the quality indicators of their performance.

A search experiment was made in order to determine the extraction force of the beet shoots from the soil and two common species of weeds cockspur grass (Echinochloa crusgalli L.) and orach Atriplex hortensis L.) with the direction of the applied force - parallel to the soil surface. As the point of the force application was chosen the stem of the plant at the level of the soil surface. The nature of the effort is static and dynamic. The sample size was 150 plant shoots of beets, cockspur grass and orach. In order to conduct the research, special instruments were developed and made to measure the extraction forces of the sugar beet plants and weeds from the soil. In the device for static application and measurement of the forces discrete application of the force is provided with steps of $0.1 \mathrm{~N}$. In the device for dynamically applying force, executed in the form of copra, there is also provided discrete application of force, expressed through the lifting angle of the feeler pendulum with a graduation mark 1 degree.

We have developed earlier a harrow for thinning sugar beet shoots by means of spring teeth, (i. e. a spring harrow in two versions - BPL-7 and BPL-9), the output of which was undertaken by the Kamenets-Podolskselmash factory. However, full implementation of many of the advantages of the spring tooth within the above-mentioned spring harrows was unsuccessful. Thus, the practice of using tooth harrows indicates that clogging of their teeth with the plant residues and soil, absence of a mechanism for the tillage depth control, and inevitability of the tractor aggregate to move across the rows of the cultivated plants, in particular the sugar beet, leads to a lower quality of crop cultivation. There is no doubt that making a spring harrow somewhat weakened the impact of the shortcomings of the tooth harrows, yet the task to develop another, a more perfect working tool, remained urgent.

Therefore, in the course of further research, a new soil loosening chain-spring tool was developed, the embodiment of which is protected by a patent [8]. It is made in the form of a chain contour made up of a chain and a drive sprocket, a driven roll and a tension roll, and in the holders on the chain there are spring teeth mounted. A scheme of the section of this working tool is presented in Fig. 1. In addition, the design parameters of the spring tooth are: the diameter of the wire is $4 \mathrm{~mm}$; the average diameter of the spring is $48 \mathrm{~mm}$; the twist angle $-50^{\circ}$; the number of working coils -3 ; the spring stiffness $-51 \mathrm{~N} \cdot \mathrm{mm} \cdot \mathrm{grad}^{-1}$; the length of the tooth $-140 \mathrm{~mm}$.

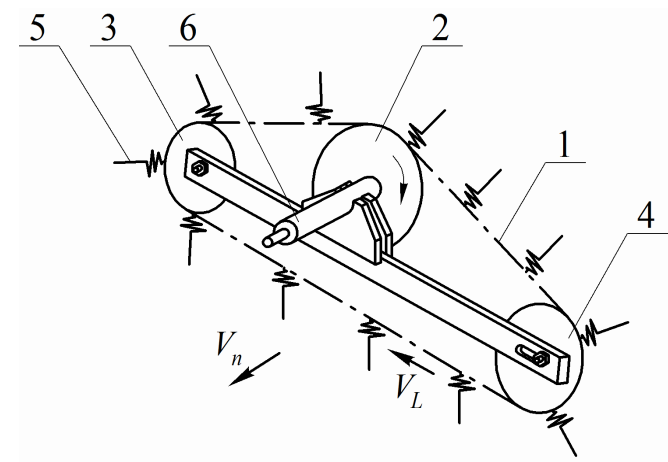

Fig. 1. Scheme of single-row section of chain working tool: 1 - chain contour; 2 - drive sprocket; 3,4 - side sprockets; 5 - spring tooth; 6 - shaft drive

The contour of the equipment is mounted on a radially-hinged suspension arm, and it is equipped with an adjustment wheel. The machine with the chain working tools may be a 4, 6 and 12-row machine. Each row of the sugar beet or other intertilled crop is cultivated by the chain working tool. In operation the machine moves along the rows of agricultural plants. The sections are installed above the rows. While moving, the chain working tool sets into movement the spring teeth arranged on the chain loosening the soil in the rows and the protective areas by the spring teeth (Fig. 2).

During the research, comparative studies of the performance quality of three types of harrows were carried out. 
As a generalising criterion for the assessment of the performance of a spring tooth of the new harrow, cultivating the sugar beet plantations, we proposed the coefficient $k_{m s}$ of mechanical selectivity for the removal of the plant shoots, which was defined by the following formula [9]:

$$
k_{m s}=\frac{k_{w}}{k_{b}},
$$

where $k_{w}$ - quantity of the destroyed weeds, pcs.;

$k_{b}-$ quantity of the removed sugar beet shoots, pcs.

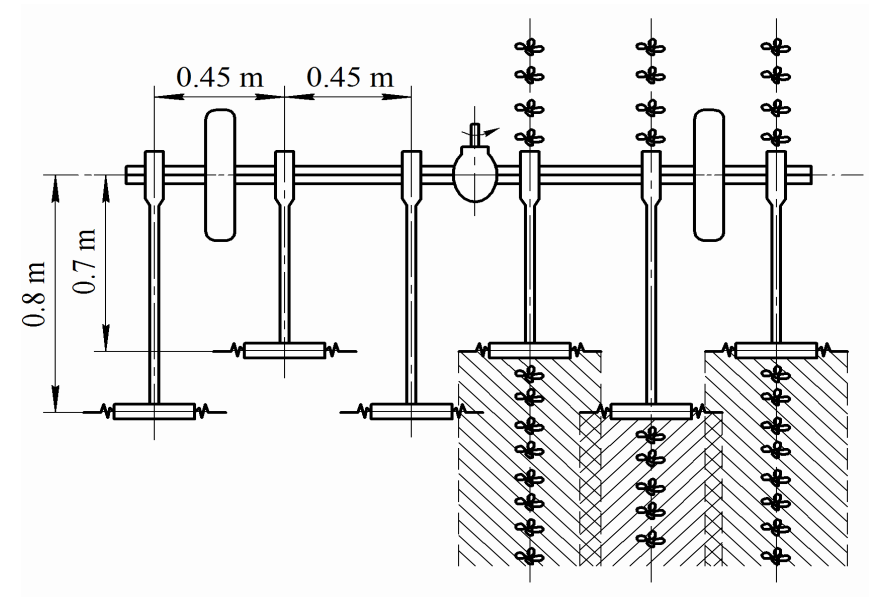

Fig. 2. Design and technological scheme of machine with chain working tools for soil tillage on sugar beet plantations

\section{Results and discussion}

In order to identify a possibility to develop more perfect working tools, there was a need for comprehensive study of the basic criteria for mechanical selectivity.

To accomplish this task, first of all, it is necessary to find agrotechnical differences between the beet shoots and the common weeds, by means of which it is possible to ensure maximum weed removal with minimal damage to the sugar beet shoots. It was found out that such differences are the degree of development of the root system of the shoots and the length of their root system. Thus, at the fork phase - when the first pair of genuine leaves appears - the root system of sugar beets reaches 4 to $30 \mathrm{~cm}$ in length, due to which such a plant is considered well-rooted. But the primary root system of the weeds: cockspur grass and orach in the same period, is still weakly developed, the length of their roots being only $0.8-2.0 \mathrm{~cm}$, which gives a reason to consider such a plant as weakly rooted.

The research results in order to determine the extraction forces of the sugar beet shoots and the most common weeds from the soil based on multiple measurements and further statistical processing on the PC are presented in Table 1.

Table 1

Average value of the extraction force of the sugar beet shoots and weeds from the soil

\begin{tabular}{|c|c|c|c|c|}
\hline \multirow{2}{*}{$\begin{array}{c}\text { Name of } \\
\text { the plant }\end{array}$} & $\begin{array}{c}\text { Stage of the } \\
\text { development of } \\
\text { the plant }\end{array}$ & $\begin{array}{c}\text { Extraction force at } \\
\text { static application of } \\
\text { force, } \mathbf{N}\end{array}$ & \multicolumn{2}{|c|}{ At dynamic application of force: } \\
\cline { 4 - 5 } Sugar beet & $\begin{array}{c}\text { The fork the } \\
\text { first pair of } \\
\text { leaves }\end{array}$ & 6.2 & 49 & 4.4 \\
& the weight, deg. & $\begin{array}{c}\text { Intensity of } \\
\text { force, } \mathbf{~}\end{array}$ \\
\hline $\begin{array}{c}\text { Cockspur } \\
\text { grass }\end{array}$ & $\begin{array}{c}\text { One or two pairs } \\
\text { of leaves }\end{array}$ & 2.7 & 28 & 2.7 \\
\hline Orach & $\begin{array}{c}\text { From two to } \\
\text { four leaves }\end{array}$ & 2.1 & 19 & 1.9 \\
\hline
\end{tabular}


As one can see from the data of Table 1, at static application of force the extraction rate of the sugar beet shoots from the soil is almost 2.3 times greater than the extraction rate of cockspur grass and almost 3 times greater than the extraction rate of orach; but at dynamic application of the extraction force the extraction rate of the sugar beet shoots from the soil is 1.6 times greater than the extraction rate of cockspur grass and 2.3 times more in comparison with orach. Consequently, such characteristics of the sugar beet shoots and the most common weeds provide good prerequisites for the creation of a working tool endowed with mechanical selectivity.

Nevertheless, the average value of the extraction force of the plant shoots does not yet provide a complete picture about the behaviour of different plant shoots when they are extracted. It is necessary to know the density $P_{(P)}$ of distribution of the extraction forces. On the basis of the results of our studies and their processing on the PC, we constructed graphs of dependencies of the probability density $P_{(P)}$ upon the magnitude $R$ of the extraction force of the shoots from the soil, shown in Fig. 3.

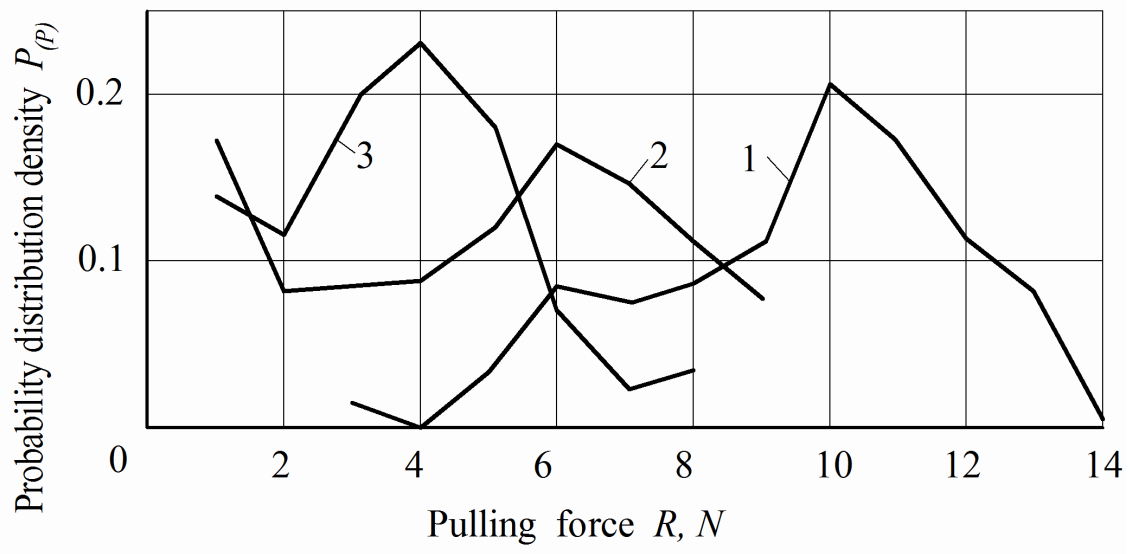

Fig. 3. Density distribution of probability $P_{(P)}$ of extraction force $R$ of shoots from soil: 1 - sugar beet; 2 - cockspur grass; 3 - orach

From the graphs of Figure 1 one can see that the regions $P_{(P)}$ of distribution of the extraction forces for the shoots of different weeds only partly overlap the distribution area of forces for sugar beet, which indicates that only a part of the sugar beet shoots can be damaged; however, the most part of them can be preserved (with the existing possibility of almost complete destruction of the weeds) [7].

In scientific literature [10-12] it is indicated that the working elements that are endowed with certain flexibility, for example, the spring teeth, are able to obviate obstacles in the soil. However, this problem is little investigated and, in fact, not scientifically worked out.

We advance another scientific hypothesis that the obstacles, which the spring tooth moving in the soil to a great extent can obviate, may be well-rooted shoots of the sugar beet, in contrast to the much worse rooted shoots of the weeds. This assumption was confirmed in our further investigations.

On the basis of the results of experimental studies and their mathematical processing, three levels of the values of the mechanical selectivity coefficient $k_{m s}$ were established: I.) $k_{m s}=2.15-3.30-$ the insufficient level; II.) $k_{m s}=8.00-15.00-$ the acceptable level; III.) $k_{m s}=18.00-19.00-$ the high level. The third level of mechanical selectivity corresponds to the high efficiency of modern agricultural production. The developed spring tooth is able to implement the process of mechanical selectivity exceeding the second level $\left(k_{m s}=12.0-15.4\right)$ of removal of the plant shoots on the sugar beet plantations.

The new harrow with the chain-spring operating tools in an optimal operating mode in the range of the soil moisture ( $W=14-20 \%)$ ensures destruction of the weed shoots - from 60 to $75.1 \%$ with a removal of the sugar beet shoots from 3 to $5 \%$ (mostly poorly developed or diseased plants).

Preliminary field investigations of the impact upon the crop yields showed that the application of the developed harrow with the chain-spring working tools ensures an increase in the yield of the sugar 
beets by 1.1-4.6 $\mathrm{t} \cdot \mathrm{ha}^{-1}$ (due to reduced weediness of plantations and the removal of the diseased sugar beet shoots).

The results of comparative tests of the operation of various tools (standard teeth harrows, the spring harrow BPL-7 and the developed new harrow with the chain-spring operating elements) are presented in Table 2.

As evident from Table 2, the new harrow with the chain-spring operating tools and with the spring teeth, in contrast to the spike-tooth harrow removes the sugar beet shoots 5 times less and by $11-15 \%$ more destroys the weeds. The chain-spring working tool also ensures better results compared to the spring-tooth harrow (rigidly attached to the harrow frame).

Table 2

Comparative evaluation of the weed control devices

\begin{tabular}{|c|c|c|c|c|c|c|}
\hline \multirow[b]{2}{*}{ Devices } & \multicolumn{3}{|c|}{$\begin{array}{l}\text { At the speed of the movement of the } \\
\qquad \begin{array}{l}\text { aggregate } \\
4 \mathrm{~km} \mathrm{~h}^{-1}\end{array}\end{array}$} & \multicolumn{3}{|c|}{$\begin{array}{c}\text { At the speed of the movement of } \\
\text { the aggregate } \\
7 \mathrm{~km} \mathrm{~h}^{-1}\end{array}$} \\
\hline & $\begin{array}{c}\text { Removed } \\
\text { shoots of } \\
\text { the } \\
\text { beets, \% }\end{array}$ & $\begin{array}{c}\text { Remov } \\
\text { ed } \\
\text { weeds, } \\
\%\end{array}$ & $\begin{array}{c}\text { Coefficient of } \\
\text { mechanical } \\
\text { selectivity } \\
k_{m s}\end{array}$ & $\begin{array}{l}\text { Removed } \\
\text { shoots of the } \\
\text { beets, \% }\end{array}$ & $\begin{array}{c}\text { Remo } \\
\text { ved } \\
\text { weeds, } \\
\%\end{array}$ & $\begin{array}{c}\text { Coefficient } \\
\text { of } \\
\text { mechanica } \\
\text { I selectivity } \\
k_{m s}\end{array}$ \\
\hline $\begin{array}{l}\text { Tooth harrow } \\
\text { ZOR- } 0.7 \text { with } \\
\text { rigid teeth }\end{array}$ & 25.0 & 61.1 & 2.44 & 27.1 & 60.5 & 2.23 \\
\hline $\begin{array}{l}\text { Tooth harrow } \\
\text { BPL-7 }\end{array}$ & 12.5 & 67.5 & 5.40 & 12.8 & 68.3 & 5.33 \\
\hline $\begin{array}{l}\text { Experimental } \\
\text { harrow with } \\
\text { chain-spring } \\
\text { operating } \\
\text { elements }\end{array}$ & 5.2 & 75,1 & 13.07 & 6.3 & 73.0 & 10.54 \\
\hline
\end{tabular}

Consequently, as the results of the experimental investigations indicate, the harrow developed by us with the chain-spring working tools can compete to some extent with herbicides and find application on the fields of farms, where the ecological (biological) system of organic farming is used for cultivation of plants. It may also cause interest of other landowners, because it will be a simple multipurpose, efficient machine with a wide range of application.

\section{Conclusions}

1. The revealed agrotechnical differences between the shoots of the sugar beets and the common weeds allowed us to justify the design peculiarities of the new working tools with the use of the spring teeth. The new harrow with the chain-spring operating tools in an optimal operating mode in the range of the soil moisture $(W=14-20 \%)$ ensures destruction of the weed shoots - from 60 to $75.1 \%$ with a removal of the sugar beet shoots from 3 to $5 \%$ (mostly poorly developed or diseased plants).

2. The conducted field tests of the harrow with the chain-spring teeth showed its efficiency and advantages over the other existing harrow designs in the care for sugar beet plantations without the application of herbicides. The new harrow with the chain-spring operating tools and with the spring teeth, in contrast to the spike-tooth harrow, removes the sugar beet shoots 5 times less and by $11-15 \%$ more destroys the weeds.

\section{References}

[1] Crittenden S., Poot N., Heinen M., Van Balen D., Pulleman M. Soil physical quality in contrasting tillage systems in organic and conventional farming. Soil and Tillage Research. Vol. 154, 2015, pp.136-144. 
[2] Mack G., Hoffmann C. Organ-specific adaptation to low precipitation in solute concentration of sugar beet (Beta vulgaris L.) European Journal of Agronomy Volume 25, Issue 3, 2006, pp. 270-279.

[3] Нанаенко А. Возделывание сахарной свеклы без гербицидов (Cultivation of sugar beet without herbicides). Сахарная свекла (Sugar beet), No 4, 2002, pp. 9-11. (In Ukrainian).

[4] Vilde A. Development of technologies and machinery for production of sugar beet in Latvia. Proceedings of the conference Šafe and economocal agricultural technologies" (25-26 July, 2002, Priekuli, Latvia), 2002. pp. 62-66.

[5] Хелемендик Н. Влияние агротехнических и химических средств борьбы с сорняками на продуктивность сахарной свеклы в условиях недостаточного увлажнения (Influence of agrotechnical and chemical means of weed control on the sugar beet productivity under conditions of insufficient moisture). Борьба с сорняками при возделывании сахарной свеклы по индустриальной технологии. (Combating weeds in the cultivation of sugar beet by industrial technology). Kiev, 1983, pp. 63-68. (In Ukrainian).

[6] Rasmussen J., Greipentrog H., Nielsen J., Henriksen C. Automated intelligent rotor tine cultivation and punch planting to improve the selectivity of mechanical intra-row weed control. Weed Research, Vol. 52, Issue 4, 2012, pp. 327-337.

[7] Хелемендик Н. Пружинный зуб вместо гербицидов (A spring tooth instead of herbicides). Сахарная свекла (Sugar beet), No 7, 1998, pp. 14-15. (In Ukrainian).

[8] A patent UA 46080. Борона с пружинными зубьями (A harrow with spring teeth). Auhors: Helemendik N. et al., 2002.

[9] Булгаков В. Свеклоуборочные машины. Монография (Beet Harvesting Machines. А Monograph). Kiev, 2011. 351 p. (In Ukrainian)

[10] Segun R. Bello. Agricultural Machinery \& Mechanization. 2012, 448 p.

[11] Adamchuk V., Prysyazhnyi V., Ivanovs S., Bulgakov V. Investigations in technological method of growing potatoes under mulch of straw and its effect on the yield. Engineering for Rural Development, Proceedings, Volume 15, 2016. pp.1098-1103.

[12]Löttjönen T., Mikkola H. Three mechanical weed control techniques in spring cereals Agricultural and Food Science in Finland. Volume 9, Issue 4, 2000, pp. 269-278. 